\title{
Peroxisome Proliferator-Activated
} Receptor Gamma Negatively Regulates the Differentiation of Bone MarrowDerived Mesenchymal Stem Cells Toward Myofibroblasts in Liver Fibrogenesis

\author{
Shuangshuang Jia Xin Liu Weiyang Li Jieshi Xie Le Yang Liying Li \\ Department of Cell Biology, Municipal Laboratory for Liver Protection and Regulation of Regeneration, \\ Capital Medical University, Beijing, China
}

\section{Key Words}

Peroxisome proliferator-activated receptor gamma - Bone marrow-derived mesenchymal stem cells • Differentiation • Fibrogenesis • Transforming growth factor $\beta 1$

\begin{abstract}
Background/Aims: Bone marrow-derived mesenchymal stem cells (BMSCs) have been confirmed to have capacity to differentiate toward hepatic myofibroblasts, which contribute to fibrogenesis in chronic liver diseases. Peroxisome proliferator-activated receptor gamma $(P P A R \gamma)$, a ligand-activated transcription factor, has gained a great deal of recent attention as it is involved in fibrosis and cell differentiation. However, whether it regulates the differentiation of BMSCs toward myofibroblasts remains to be defined. Methods: Carbon tetrachloride or bile duct ligation was used to induce mouse liver fibrosis. Expressions of PPAR $\gamma, \alpha$-smooth muscle actin, collagen $\alpha 1$ (I) and collagen $\alpha 1$ (III) were detected by real-time RT-PCR and Western blot or immunofluorescence assay. Results: PPARy expression was decreased in mouse fibrotic liver. In addition, PPARY was declined during the differentiation of BMSCs toward myofibroblasts induced by transforming growth factor $\beta 1$. Activation of PPAR $\gamma$ stimulated by natural or synthetic ligands suppressed the differentiation of BMSCs. Additionally, knock down of PPARY by siRNA contributed to BMSC differentiation toward myofibroblasts. Furthermore, PPARY activation by natural ligand significantly inhibited the differentiation of BMSCs toward myofibroblasts in liver fibrogenesis and alleviated liver fibrosis. Conclusions: PPAR $\gamma$ negatively regulates the differentiation of BMSCs toward myofibroblasts, which highlights a further mechanism implicated in the BMSC differentiation.
\end{abstract}




\section{Cellular Physiology Cell Physiol Biochem 2015;37:2085-2100 and Biochemistry Published online: November 25, 2015 www.karger.com/cpp \\ Jia et al.: PPARy Negatively Regulates the Differentiation of BMSCs}

\section{Introduction}

Liver fibrosis is characterized by overproduction of collagen, especially collagen $\alpha 1$ (I) (Col $\alpha 1$ (I)) and collagen $\alpha 1$ (III) (Col $\alpha 1$ (III)), and other extracellular matrix (ECM) components $[1,2]$. Myofibroblasts, characterized by the cytoskeletal protein $\alpha$-smooth muscle actin ( $\alpha$-SMA), are known to be the predominant cells to generate $\mathrm{Col} \alpha 1$ (I) and Col $\alpha 1$ (III). In addition to hepatic stellate cells (HSCs), portal fibroblasts, circulating fibrocytes and epithelial-mesenchymal transition (EMT), bone marrow (BM)-derived cells have recently been considered as another origin of hepatic myofibroblasts [2-4]. In particular, by using lethally irradiated female mice which receive male BM transplants, and tracking BMderived cells through in situ hybridization for the Y chromosome, Russo et al. [5] found that $70 \%$ of hepatic myofibroblast populations are from BM-derived mesenchymal stem cells (BMSCs). In keeping with this finding, we also proved that a significant proportion of hepatic myofibroblasts is of BMSC-differentiation origin with a model of lethally irradiated mice receiving BM transplants from enhanced green fluorescent protein (EGFP) transgenic mice [6]. Considering the importance of BMSCs in liver fibrosis, identification of the molecular mechanisms underlying BMSC differentiation toward myofibroblast may represent an effective strategy for the treatment of fibrotic liver disease.

Transforming growth factor $\beta 1$ (TGF- $\beta 1$ ) is a key profibrotic cytokine in the fibrogenesis [7-10], and can induce the differentiation of several sorts of fibroblasts toward myofibroblasts in vitro, such as fibroblasts from skin, lung, kidney and heart origin [11-14]. Our previous study has demonstrated that sphingosine kinase/sphingosine 1-phosphate (S1P)/S1P receptor axis is involved in the differentiation of BMSCs toward myofibroblasts induced by TGF- $\beta 1$ during liver fibrosis [9]. Nevertheless, it is still not clearly illustrated whether other molecules implicated in this process and the underlying mechanisms.

Peroxisome proliferator-activated receptors (PPARs) are ligand-activated transcription factors belonging to the nuclear hormone receptor superfamily [15], with three subtypes, PPAR $\alpha, \operatorname{PPAR} \beta / \delta$ and PPAR $\gamma$, relate to multiple functions, including metabolism, immune responses and cellular proliferation [16]. PPAR $\gamma$ is mainly known to regulate adipocyte differentiation and fatty-acid uptake and storage [17-19]. Some clinical studies reported that synthetic PPAR $\gamma$ agonists, such as thiazolidinedione, have beneficial effects in patients with type 2 diabetes [20,21]. Besides its function in metabolism, a new action of PPAR $\gamma$ in fibrosis has been revealed. It has been reported that activation of PPAR $\gamma$ by specific agonists could ameliorate fibrosis in several organs, such as lung, kidney and heart [22]. In particular, several recent studies have illustrated that PPAR $\gamma$ participates in the myofibroblast differentiation $[11,13,23,24]$. However, whether PPAR $\gamma$ is link to regulate the differentiation of BMSCs toward hepatic myofibroblasts and its molecular mechanisms remain obscure.

Based on the scientific background, the aim of this study is to elucidate the function of PPARy in BMSCs differentiation toward myofibroblasts in liver fibrogenesis. Here, we showed that PPAR $\gamma$ expression was reduced in mouse liver fibrogenesis, as well as in the differentiation of primary mouse BMSCs toward myofibroblasts induced by TGF- $\beta 1$ in vitro. In addition, knock down of PPAR $\gamma$ by siRNA contributed to the differentiation of BMSCs. Furthermore, activation of PPAR $\gamma$ by ligands inhibited BMSCs differentiation toward myofibroblasts in vitro and in vivo, and ameliorated liver fibrosis. These observations strongly indicate that PPAR $\gamma$ negatively governs the differentiation of BMSCs toward myofibroblasts, suggesting that PPAR $\gamma$-targeted therapy could be a potential strategy in the treatment of liver fibrosis.

\section{Materials and Methods}

Reagents

$\alpha$-MEM was from Invitrogen (Grand Island, NY). Fetal bovine serum was from Hyclone/Thermo Scientific (Victoria, Australia). TGF- $\beta 1$ came from PeproTech (London, UK). 15d-PGJ ${ }_{2}$ was from Cayman Chemi- 


\section{Cellular Physiology Cell Physiol Biochem 2015;37:2085-2100 \begin{tabular}{ll|l}
\hline DOI: 10.1159/000438567 & (c) 2015 The Author(s). Published by S. Karger AG, Basel
\end{tabular} and Biochemistry Published online: November 25, 2015 www.karger.com/cpb \\ Jia et al.: PPARy Negatively Regulates the Differentiation of BMSCs}

cal (Ann Arbor, MI). Troglitazone and ciglitazone were from Biomol (Tebu, France). Antibodies against PPAR $\gamma$, Col a1 (I), Col a1 (III) and tubulin were from Santa Cruz Biotechnology (CA, USA). Anti-glyceraldehyde-3-phosphate dehydrogenase (GAPDH) monoclonal antibody was from Cell Signalling (Beverly, MA). PCR reagents were from Applied Biosystems (Foster City, CA). Anti- $\alpha$-SMA antibody, bovine serum albumin (BSA) and other common reagents were from Sigma-Aldrich (St. Louis, MO).

\section{BMSCs preparation}

BM cells were isolated from bone marrow by flushing the tibias and femurs of ICR mice aged 3 weeks (Laboratory Animal Center, Capital Medical University) with culture medium using a 25-gauge needle. The cells were then passed through 70-mm nylon mesh and were washed three times with PBS containing 2\% fetal bovine serum. BMSCs cultured as described previously [5]. In brief, BM cells were cultured with BMSCs culture medium ( $\alpha$-MEM) containing $20 \%$ fetal bovine serum for 1 week at $37^{\circ} \mathrm{C}$ in $5 \% \mathrm{CO}_{2}$. To remove the nonadherent cells, the culture medium was replaced twice a week. $\alpha$-MEM containing $15 \%$ fetal bovine serum was used to culture BMSCs after the first subculture. BMSCs are characterized by the phenotypes as positive for CD44, CD105 and CD166, but negative for CD14, CD34 and CD45 in flow cytometry analysis [6]. BMSCs of passage 3 to passage 5 were used in the experiments. All animal work was performed under the ethical guidelines of the Ethics Committee of Capital Medical University.

Mouse models of liver fibrosis

Mouse models of chronic liver fibrosis were performed by injection of carbon tetrachloride $\left(\mathrm{CCl}_{4}\right)$ or bile duct ligation (BDL). ICR mice aged 6 weeks received intraperitoneal injections of $1 \mu \mathrm{L} / \mathrm{g}$ body weight of a $\mathrm{CCl}_{4} /$ olive oil (OO) mixture, $1: 9 \mathrm{v} / \mathrm{v}$, twice per week. $15 \mathrm{~d}-\mathrm{PGJ}_{2}(0.3 \mathrm{mg} / \mathrm{kg}$ body weight $)$ or saline was administrated the day before $\mathrm{CCl}_{4}$ or $\mathrm{OO}$ treatment, and then twice per week before $\mathrm{CCl}_{4}$ or $\mathrm{OO}$ treatment for indicated times. The mice were sacrificed at 1,3 days or at $1,2,4$, or 8 weeks of $\mathrm{CCl}_{4}$ treatment $(\mathrm{n}=7$ per group).

Another group of adult ICR mice received BDL operation as described previously [25]. In brief, mice were anesthetized to receive a midline laparotomy to expose the common bile duct which was ligated three times. One ligature was located in the distal portion of the bile duct and another two were placed in the proximal portion. Then, the bile duct was cut between the ligatures followed by closing the abdomen in layers. Sham-operated mice underwent a laparotomy with exposure, but no performance of ligation of the common bile duct, which used as controls. Mice were sacrificed at 3 days or at 1,2 weeks of BDL $(n=7$ per group).

\section{BM transplantation}

ICR mice received lethal irradiation (8 Grays), and then immediately received transplantation by a tail-vein injection of $1.5 \times 10^{7}$ whole BM cells obtained from 3-week-old EGFP transgenic mice. Four weeks later, mice received intraperitoneal injections of $\mathrm{CCl}_{4}$ twice per week for 4 weeks. $15 \mathrm{~d}-\mathrm{PGJ} \mathrm{J}_{2}(0.3 \mathrm{mg} / \mathrm{kg}$ body weight) or saline was applied the day before $\mathrm{CCl}_{4}$ or 00 injection, and twice per week before $\mathrm{CCl}_{4}$ or 00 treatment for 4 weeks ( $\mathrm{n}=7$ per group).

Quantitative analysis of liver fibrosis

Liver tissues were fixed in $4 \%$ paraformaldehyde for 24 hours and embedded in paraffin. Samples were cut into $5 \mu \mathrm{m}$ slices and sections were stained for collagen visualization with Sirius Red.

\section{Immunofluorescence and high content analysis}

BMSCs with or without treatments were fixed in $4 \%$ paraformaldehyde in PBS for 30 minutes. Then cells were washed twice with PBS, permeabilized in 0.5\% Triton X-100 for 15 minutes, blocked with 2\% BSA for 1 hour, and incubated with antibodies to $\alpha$-SMA (1:1000), Col a1(I) (1:100), Col a1(III) (1:200) and PPAR $\gamma$ (1:100) overnight, followed by secondary antibody conjugated with Cy3 (1:500, Jackson Immunoresearch Laboratories, West Grove, PA) for 1 hour. Cells were washed twice with PBS after incubation with PBS containing $10 \mu \mathrm{g} / \mathrm{mL}$ DAPI for 5 minutes, and $200 \mu \mathrm{L}$ PBS were left in each well. For negative controls, cells were processed the same way, except the primary antibody was omitted. The plates were imaged on a Thermo Scientific Cell Insight personal cell imaging (PCI) platform (Cellomics, Inc., Thermo Fisher Scientific Inc., Waltham, MA), with a $\times 10$ objective using the Thermo Scientific Cellomics iDEV Software. 


\section{Cellular Physiology Cell Physiol Biochem 2015;37:2085-2100

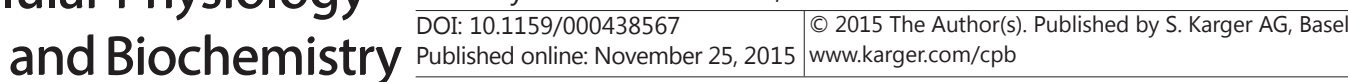 \\ Jia et al.: PPARy Negatively Regulates the Differentiation of BMSCs}

High content analysis was performed as described previously [26]. In brief, at least 3,000 cells in thirty-six fields were automatically acquired by the software. The fluorescence intensity in each well was analyzed using Cellomics Cell Health Profiling BioApplication software.

Immunofluorescent detection for $\alpha$-SMA in liver tissue was performed with a Vector M.O.M. (mouseon-mouse) immunodetection kit (Vector Laboratories) [9]. Prepared liver sections were $5 \mu \mathrm{m}$ and antibody to $\alpha$-SMA was a 1:1000 dilution.

\section{Western blot analysis}

Western blot analysis of $\alpha$-SMA, Col $\alpha 1(\mathrm{I})$, Col $\alpha 1(\mathrm{III})$ and PPAR $\gamma$ in BMSCs or liver tissue were performed with $50 \mu \mathrm{g}$ of protein extract using primary antibodies of $\alpha$-SMA (1:1000), Col $\alpha 1$ (I) (1:100), Col $\alpha 1$ (III) (1:200) and PPAR $\gamma$ (1:500). The bands were displayed using ODYSSEY and quantified by Odyssey v3.0 software. Results were normalized relative to the GAPDH (1:1000) or tubulin (1:1000) expression to correct for variations in protein loading and transfer.

\section{RNA interference}

The siRNA sequence specifically targeting mouse PPAR $\gamma$ was synthesized by Dharmacon: L-040712-000005 (Thermo Scientific, Lafayette, CO). 40\% to 50\% confluent BMSCs were prepared. Transient transfection of siRNA ( $40 \mathrm{nmol} / \mathrm{L}$ ) was performed by using Invitrogen Lipofectamine RNAiMAX, as recommended by the manufacturer. Control cells were treated with $40 \mathrm{nmol} / \mathrm{L}$ RNAi Negative Control Duplexes (scramble siRNA). Cells were collected to perform real-time RT-PCR and Western blot analysis after 48 hours.

\section{Real-time RT-PCR}

Total RNA was extracted from frozen liver specimens or cultured BMSCs with or without treatments, using an RNeasy kit (Qiagen, Hilden, Germany). Real-time RT-PCR was performed with an ABI Prism 7300 sequence-detecting system (Life Technologies, Foster City, CA), as described previously [6]. Primers (MWG Biotech, Ebersberg, Germany) used for real-time RT-PCR were as follows: 18s rRNA, sense, 5'-GTA ACC CGT TGA ACC CCA TT-3', and anti-sense, 5'-CCA TCC AAT CGG TAG TAG CG-3'; $\alpha$-SMA: sense, 5'-ATG CTC CCA GGG CTG TTT T-3', and anti-sense, 5'-TTC CAA CCA TTA CTC CCT GAT GT-3'; Col $\alpha 1$ (I): sense, 5'-AGG GCG AGT GCT GTG CTT T-3', and anti-sense, 5'-CCC TCG ACT CCT ACA TCT TCT GA-3'; Col $\alpha 1$ (III): sense, 5'-TGA AAC CCC AGC AAA ACA AAA-3', and anti-sense, 5'-TCA CTT GCA CTG GTT GAT AAG ATT AA-3'; TGF- $\beta 1$ : sense, 5'-TGC GCT TGC AGA GAT TAA AA-3', and anti-sense, 5'-TCA CTG GAG TTG TAC GGC AG-3'; PPAR $\gamma$ : sense, 5'-GCC CAC CAA CTT CGG AAT C-3', and anti-sense, 5'-TGC GAG TGG TCT TCC ATC AC-3'.

Statistical analysis

All results were confirmed in three independent experiments. Data are expressed as mean \pm SEM and were analyzed by Student's t-test or ANOVA for analysis of variance. Statistical significance was defined as $P<0.05$

\section{Results}

PPAR $\gamma$ is down-regulated in mouse chronic liver fibrogenesis

There are recent reports that expression of PPAR $\gamma$ is decreased in fibrogenesis $[13,27$, 28]. We assessed PPAR $\gamma$ content in liver tissue of mouse chronic liver fibrosis models induced by $\mathrm{CCl}_{4}$ administration or BDL operation. The results showed that PPAR $\gamma$ expression in both mRNA and protein levels were markedly reduced in $\mathrm{CCl}_{4}$ administration group compared with 00-treated group (Fig. 1A and B). These findings were consistent with the results in BDL-induced liver fibrogenesis (Fig. 1C and D).

The expressions of main ECM, Col $\alpha 1$ (I) and Col $\alpha 1$ (III), were up-regulated in mouse liver fibrogenesis [29]. Here, we undertook correlation analysis between PPAR $\gamma$ and the two molecules in liver tissue. Results presented in Fig. 1E and F demonstrated that the mRNA level of PPAR $\gamma$ had negative correlations with Col $\alpha 1$ (I) and Col $\alpha 1$ (III), respectively (correlation coefficient $\mathrm{r}=-0.503, P=0.024 ; \mathrm{r}=-0.525, P=0.025$, respectively). In addition, the expression of $\alpha$-SMA, a marker of myofibroblasts, which produces ECM predominantly, 


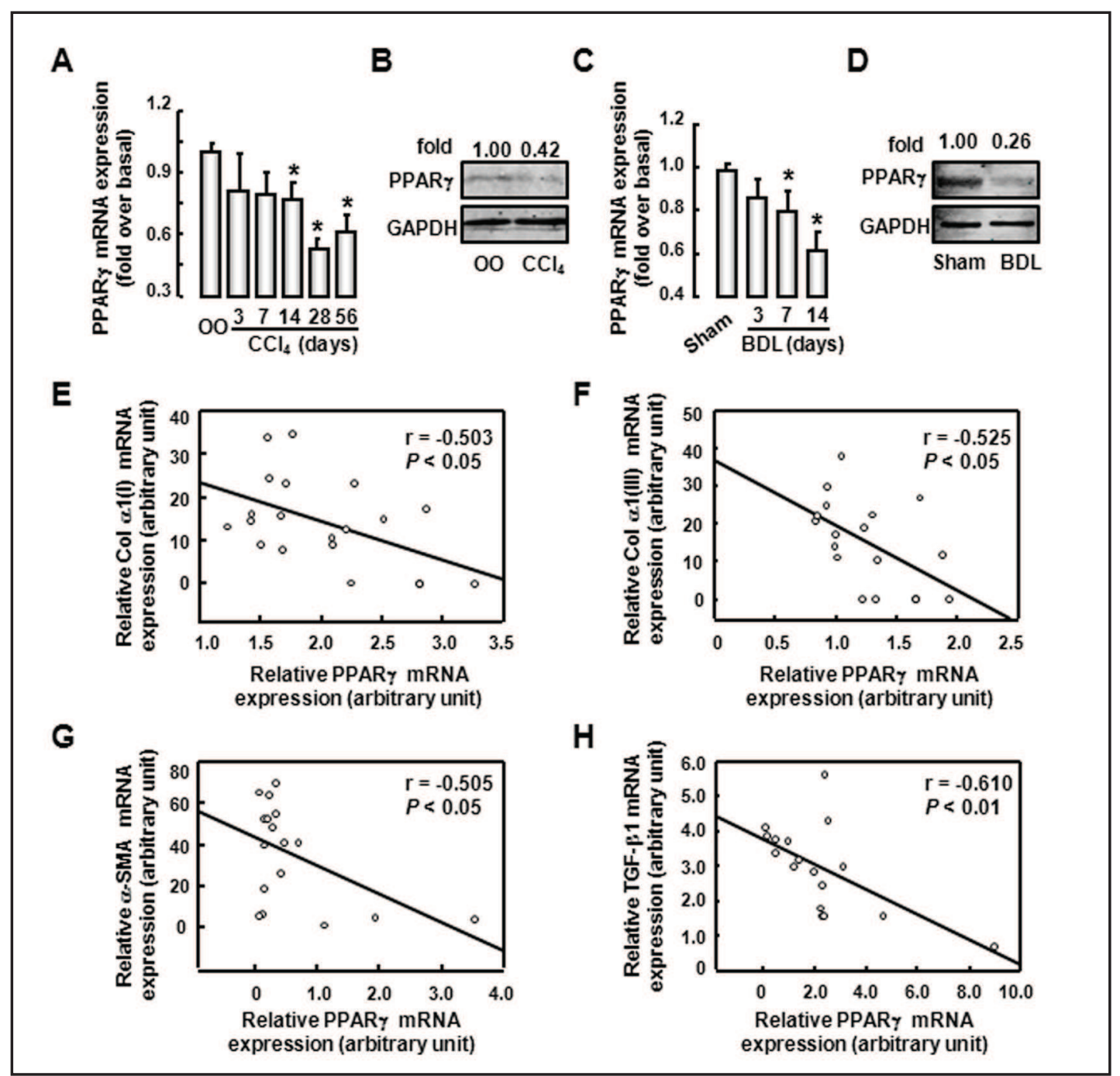

Fig. 1. PPAR $\gamma$ is involved in the chronic liver fibrogenesis. Real time RT-PCR was performed to determine mRNA expression of PPAR $\gamma$ in mouse fibrotic liver induced by $\mathrm{CCl}_{4}$ treatment (A) or BDL operation (C) ( $\mathrm{n}=7$ per group). PPAR $\gamma$ protein expressions in $\mathrm{CCl}_{4}$ treatment (4 weeks, $\mathrm{B}$ ) or BDL operation (2 weeks, D) were detected by Western blot. The correlations between mRNA expression of PPAR $\gamma$ and Col $\alpha 1$ (I) (E), Col $\alpha 1$ (III) (F), $\alpha$-SMA (G) or TGF- $\beta 1(\mathrm{H})$ in liver tissue. ${ }^{*} P<0.05$, compared with olive oil (OO) or sham group.

was obviously increased as well after liver injury [29]. We also found a negative correlation between the mRNA levels of PPAR $\gamma$ and $\alpha$-SMA (correlation coefficient $r=-0.505, P=0.039$ ) (Fig. 1G). Furthermore, there was a significant negative correlation between mRNA levels of PPAR $\gamma$ and TGF- $\beta 1$, a key profibrotic cytokine and contributing to BMSC differentiation toward myofibroblasts in fibrotic liver [9] (correlation coefficient $r=-0.610, P=0.009$ ) (Fig. 1H). Collectively, these results suggested PPAR $\gamma$ might play an essential role in liver fibrogenesis.

PPARY is down-regulated in the differentiation of BMSCs toward myofibroblasts

In addition to representing the extent of liver fibrosis, presence of $\alpha$-SMA and increased levels of Col $\alpha 1$ (I) and Col $\alpha 1$ (III) also denote the differentiation of BMSCs toward myofibroblasts [9]. Given that PPAR $\gamma$ was negatively correlated with these molecules and TGF- $\beta 1$ in liver tissue, we then sought to determine the effects of PPAR $\gamma$ on the differentiation of BMSCs. In this regard, we explored the abundance of PPAR $\gamma$ in the context of BMSC 


\section{Cellular Physiology Cell Physiol Biochem 2015;37:2085-2100 and Biochemistry Published online: November 25, $2015 \mid \begin{aligned} & \text { O 2015 The Author(s). Published by S. Karger AG, Base } \\ & \text { wwrger.com/cpb }\end{aligned}$

Fig. 2. PPAR $\gamma$ is implicated in the differentiation of BMSCs toward myofibroblasts. (A) Immunofluorescence analysis of PPAR $\gamma$ (red) in BMSCs with $(+)$ or without (-) TGF- $\beta 1$ (10 ng/mL). (B) PPAR $\gamma$ mRNA in differentiated BMSCs induced by indicated doses of TGF- $\beta 1$ for 24 hours. (C) Protein level of PPAR $\gamma$ in BMSCs treated with 10 ng/mL TGF- $\beta 1$ for 24 hours. Correlations between PPAR $\gamma$ and $\alpha$-SMA (D), Col $\alpha 1$ (I) (E) or Col $\alpha 1$ (III) (F) in BMSCs. All results were confirmed in three in d e pendent experiments. ${ }^{*} P$ $<0.05$, compared with control. Scale bars, 50 $\mu \mathrm{m}$.
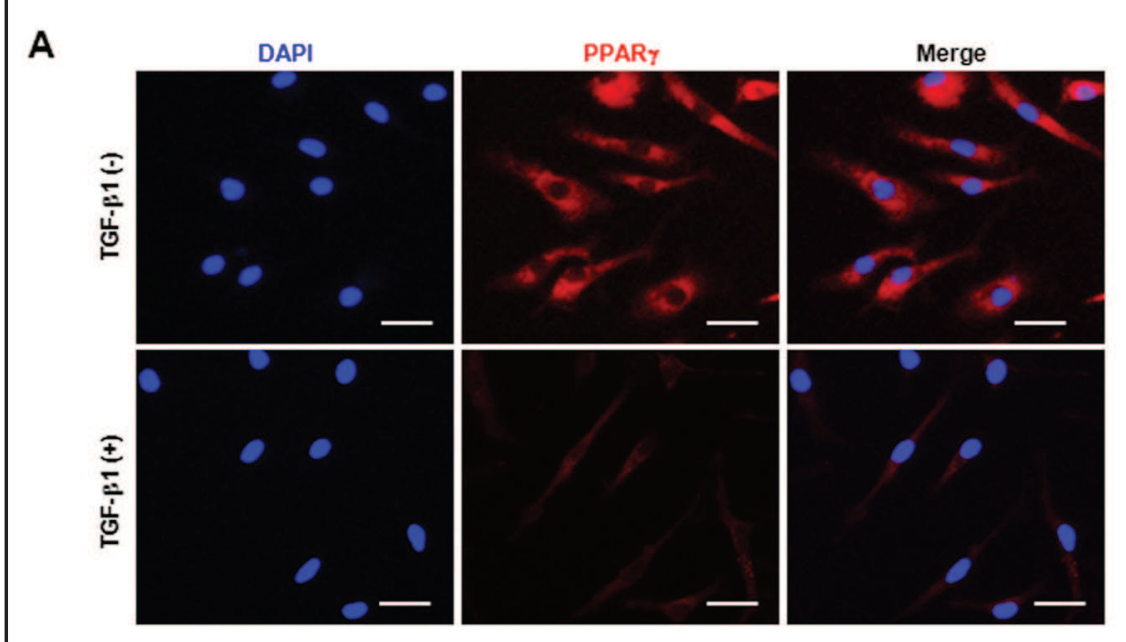

B

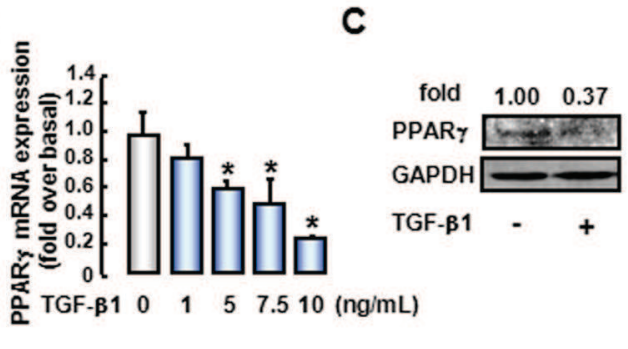

D

\section{E}

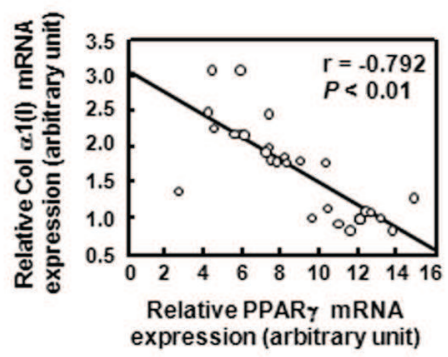

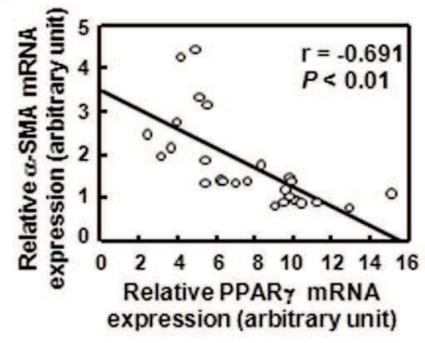

F

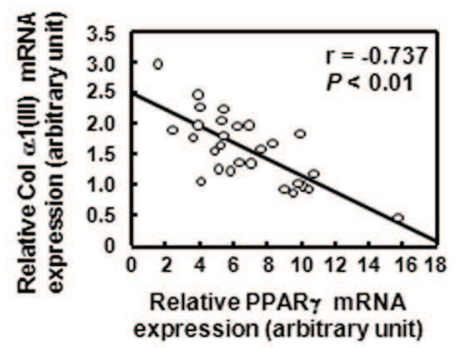

differentiation toward myofibroblasts in vitro. Immunofluorescent staining showed that the degree of positive staining for PPAR $\gamma$ was much weakened when BMSCs were induced differentiation toward myofibroblasts by TGF- $\beta 1$ (Fig. 2A). Furthermore, the mRNA level of PPAR $\gamma$ was strikingly decreased during differentiation of BMSCs trigged by TGF- $\beta 1$ in a dosedependent manner (Fig. 2B). In parallel, PPAR $\gamma$ expression in protein level was attenuated, too (Fig. 2C). It was noteworthy that there were also inverse correlations between mRNA expressions of PPAR $\gamma$ and $\alpha$-SMA, Col $\alpha 1$ (I) or Col $\alpha 1$ (III) in BMSCs (Fig. 2D-F) (correlation coefficient $\mathrm{r}=-0.691, P=0.000046 ; \mathrm{r}=-0.792, P=0.000001 ; \mathrm{r}=-0.737, P=0.000008$, respectively). These observations highlight the link between PPAR $\gamma$ and the differentiation of BMSCs toward myofibroblasts.

PPAR $\gamma$ negatively modulates the differentiation of BMSCs toward myofibroblasts

To further characterize the function of PPAR $\gamma$ in BMSC differentiation, we used an endogenous ligand (15d-PGJ $)_{2}$ ) and two synthetic ligands (troglitazone and ciglitazone) of PPAR $\gamma$. As illustrated in Fig. 3A, $\alpha$-SMA mRNA in differentiated BMSCs triggered by TGF- $\beta 1$ 

Cellular Physiology Cell Physiol Biochem 2015;37:2085-2100 \begin{tabular}{ll|l}
\cline { 1 - 2 } DOI: 10.1159/000438567 & (c) 2015 The Author(s). Published by S. Karger AG, Basel
\end{tabular} Published online: November 25, 2015 www.karger.com/cpb

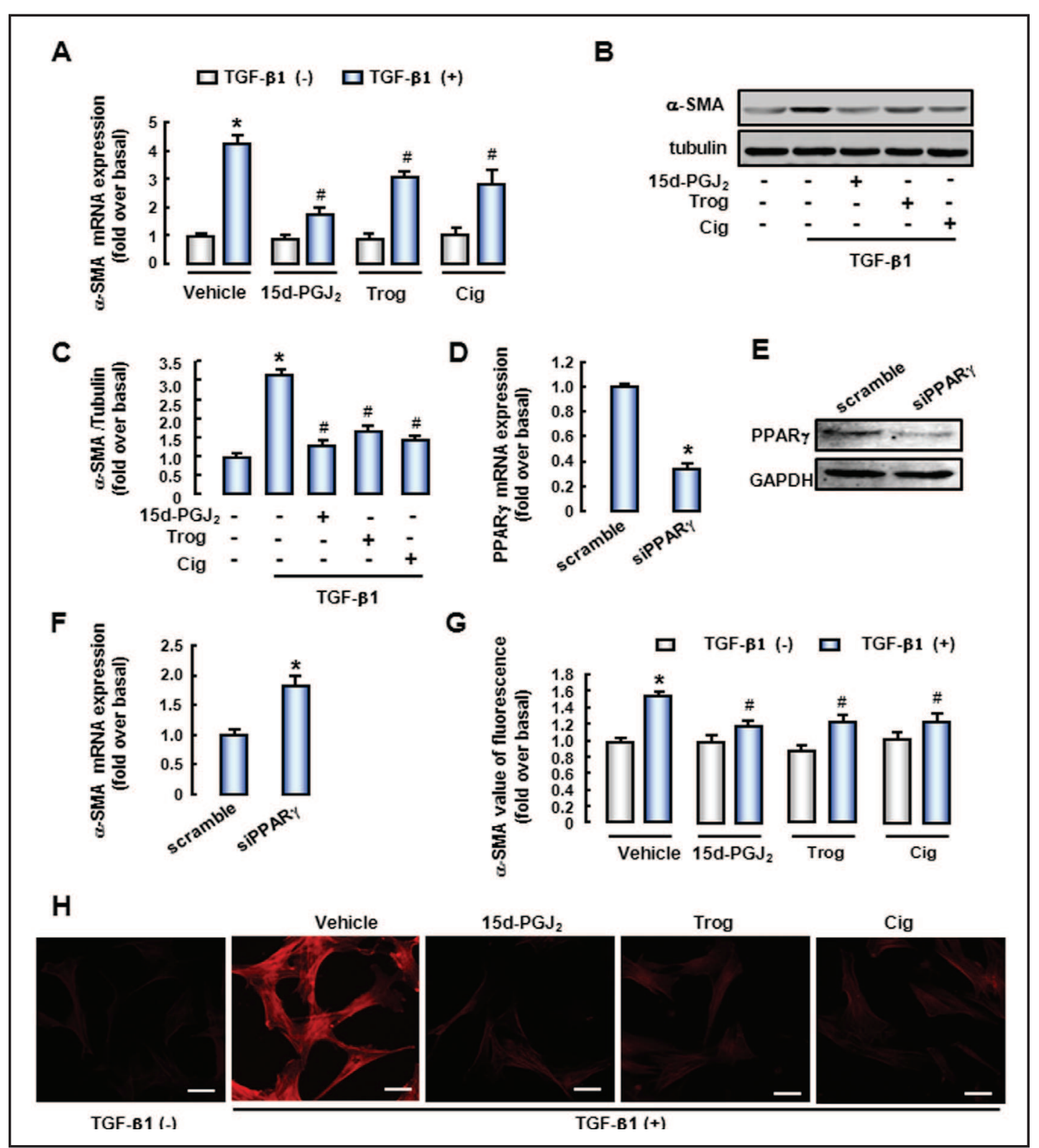

Fig. 3. Activated PPAR $\gamma$ negatively regulates $\alpha$-SMA expression in BMSCs. BMSCs were exposed to $5 \mu \mathrm{mol} / \mathrm{L}$ endogenous PPAR $\gamma$ ligand $\left(15 \mathrm{~d}-\mathrm{PGJ}{ }_{2}\right.$ ) or $10 \mu \mathrm{mol} / \mathrm{L} \mathrm{PPAR} \gamma$ synthetic agonists (troglitazone (Trog) or ciglitazone (Cig)) for 1 hour, then challenged by $10 \mathrm{ng} / \mathrm{mL}$ TGF- $\beta 1$ for 24 hours. Real time RT-PCR was performed to detect $\alpha$-SMA mRNA (A). $\alpha$-SMA protein expression was evaluated by Western blot (B). The intensity of each band with $\alpha$-SMA antibody was quantified and normalized to that with anti- $\beta$-tubulin antibody (C). $(\mathrm{H})$ Immunofluorescence analysis of $\alpha$-SMA (red), and total fluorescence intensity of $\alpha$-SMA protein was counted with high content analysis (G). Cells were transfected with scrambled siRNA or PPAR $\gamma$ siRNA for 48 hours. Protein level of PPAR $\gamma$ was detected by Western blot (E) and mRNA expression of PPAR $\gamma$ and $\alpha$-SMA was measured by real-time RT-PCR (D and F). All results were confirmed in three independent experiments. $* P<0.05$, compared with control. \# $P<0.05$, compared to TGF- $\beta 1$ group. Scale bars, $50 \mu \mathrm{m}$.

was obviously diminished when pretreatment with either natural or synthetic ligands of PPAR $\gamma$. In accord, $\alpha$-SMA protein expression induced by TGF- $\beta 1$ was down-regulated by $15 \mathrm{~d}-\mathrm{PGJ}{ }_{2}$, troglitazone or ciglitazone (Fig. 3B and C). Furthermore, siRNA technology was 


\section{Cellular Physiology Cell Physiol Biochem 2015;37:2085-2100 \begin{tabular}{l|ll} 
DOI: 10.1159/000438567 & ( ) 2015 The Author(s). Published by S. Karger AG, Basel
\end{tabular}

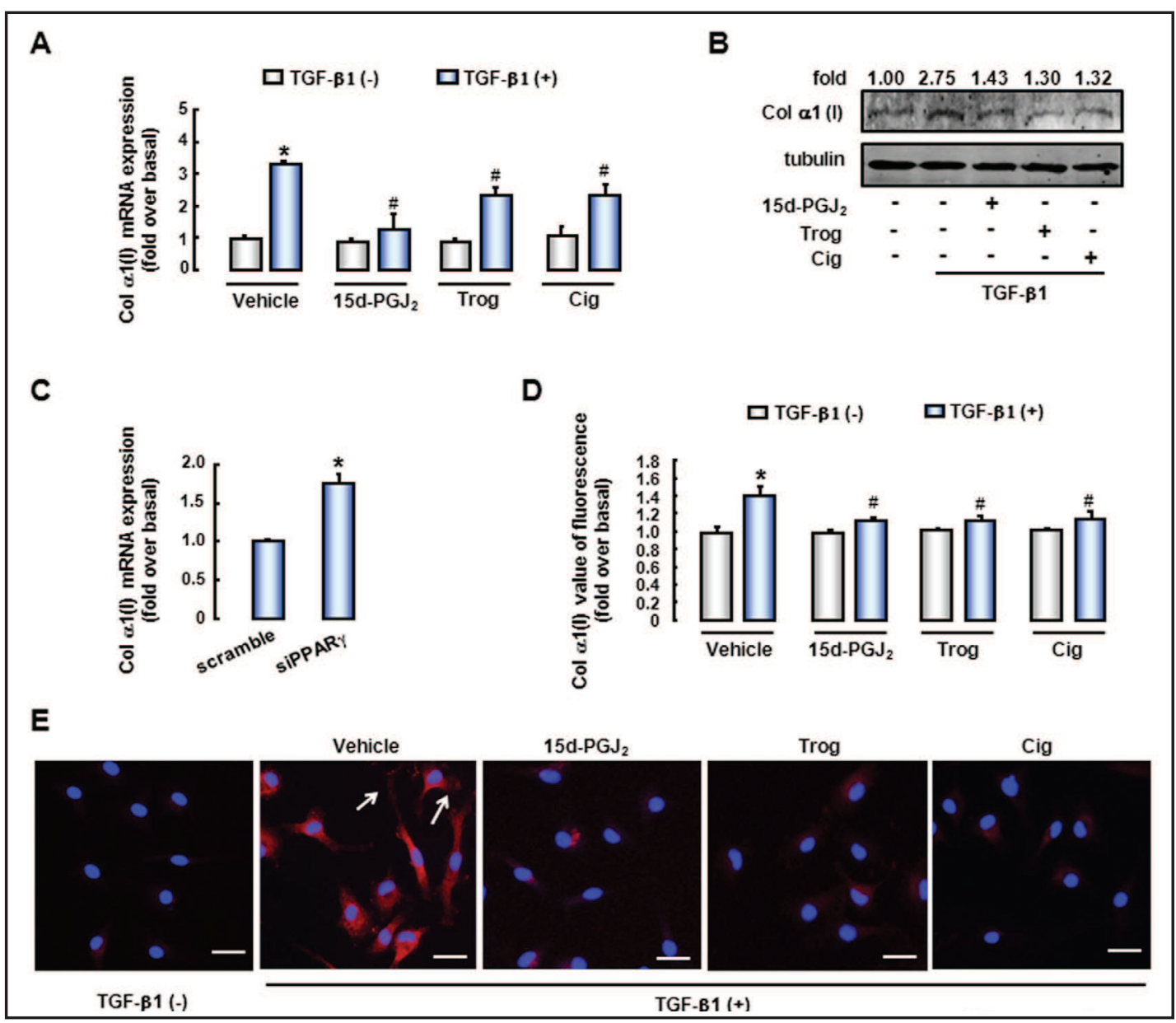

Fig. 4. PPAR $\gamma$ activation suppresses Col $\alpha 1$ (I) expression in BMSCs. BMSCs were incubated with $5 \mu \mathrm{mol} / \mathrm{L}$ $15 \mathrm{~d}-\mathrm{PGJ}_{2}, 10 \mu \mathrm{mol} / \mathrm{L}$ troglitazone (Trog) or $10 \mu \mathrm{mol} / \mathrm{L}$ ciglitazone (Cig) for 1 hour, followed by treatment of $10 \mathrm{ng} / \mathrm{mL}$ TGF- $\beta 1$ for 24 hours. mRNA expression of Col a1(I) was examined by real-time RT-PCR (A). Col $\alpha 1$ (I) protein expression was detected by Western blot (B), immunofluorescence analysis (red) (E) and high content analysis (D). Arrows in (E) indicated that Col $\alpha 1$ (I) secreted into the medium. (C) Cells were transfected with scrambled siRNA or PPAR $\gamma$ siRNA, and Col $\alpha 1$ (I) mRNA was evaluated 48 hours later. All results were confirmed in three independent experiments. ${ }^{*} P<0.05$, compared with control; $\# P<0.05$, compared with TGF- $\beta 1$ group. Scale bars, $50 \mu \mathrm{m}$.

performed to knock-down of PPAR $\gamma$. Transfection of BMSCs with PPAR $\gamma$-siRNA decreased the mRNA expression of PPAR $\gamma$ by 70\% (Fig. 3D). Meanwhile, Western blot analysis indicated PPAR $\gamma$ protein expression was also significantly reduced after knock-down of PPAR $\gamma$ (Fig. $3 \mathrm{E})$. The results showed that PPAR $\gamma$ knock-down enhanced $\alpha$-SMA mRNA expression, whereas scrambled siRNA (SCR siRNA) had no effects (Fig. 3F).

To further confirm the function of PPAR $\gamma$ in BMSC differentiation, we performed immunofluorescent staining for $\alpha$-SMA to reveal morphological changes in BMSCs. Isolated BMSCs showed very weak expression of $\alpha$-SMA under normal condition. TGF- $\beta 1$ treatment resulted in the appearance of numerous bundles of actin microfilaments and dramatically increased the expression of $\alpha$-SMA in BMSCs (Fig. 3H). However, when BMSCs were pretreated with ligands of PPAR $\gamma$, the ability of TGF- $\beta 1$ to enhance the expression of $\alpha$-SMA was markedly blunted (Fig. $3 \mathrm{H}$ ). Additionally, the total fluorescence intensity of $\alpha$-SMA examined by high content analysis demonstrated that exposure to $15 \mathrm{~d}-\mathrm{PGJ}{ }_{2}$, troglitazone or ciglitazone resulted in reducing $\alpha$-SMA protein level in differentiated BMSCs initiated by TGF- $\beta 1$ (Fig. 3G). 


\section{Cellular Physiology Cell Physiol Biochem 2015;37:2085-2100

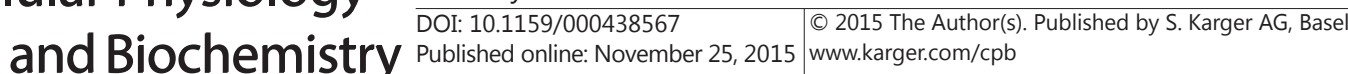

A

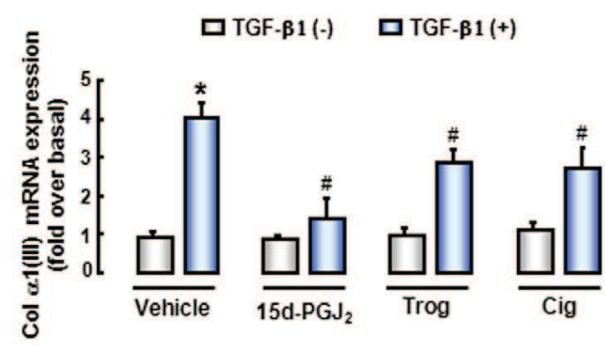

B

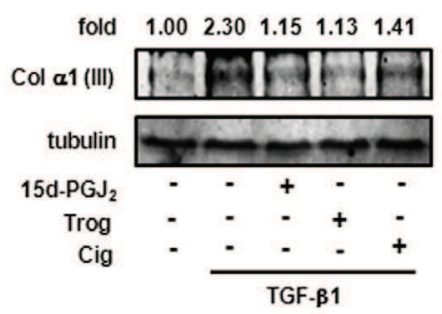

C

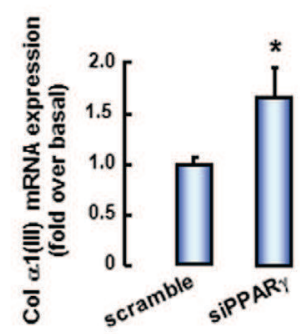

E

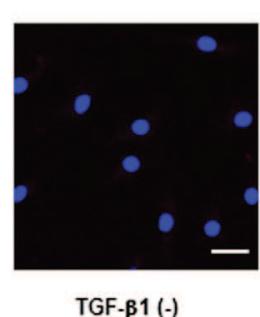

Vehicle

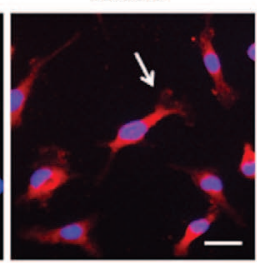

$15 \mathrm{~d}-\mathrm{PGJ} \mathrm{J}_{2}$

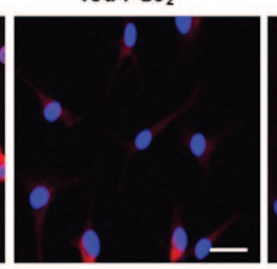

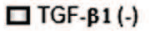

\section{口TGF- $\beta 1(+)$}
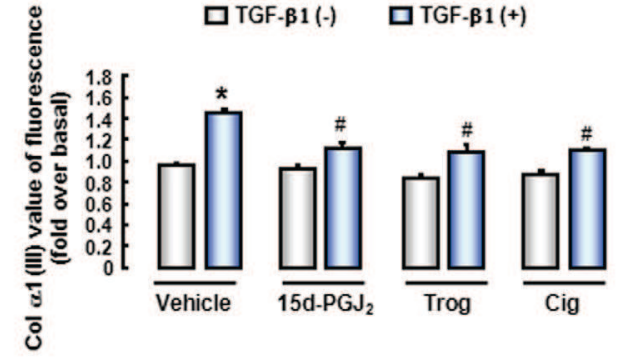

Trog

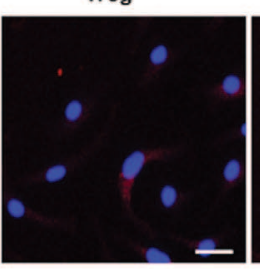

Cig

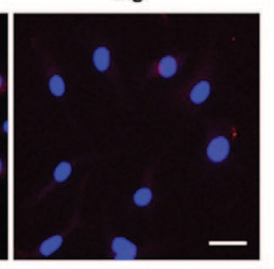

TGF-B1 (+)

Fig. 5. Activation of PPAR $\gamma$ represses expression of Col $\alpha 1$ (III) in BMSCs. BMSCs were pretreated with $15 \mathrm{~d}-\mathrm{PGJ}{ }_{2}(5 \mu \mathrm{mol} / \mathrm{L}$ ), troglitazone (Trog, $10 \mu \mathrm{mol} / \mathrm{L}$ ) or ciglitazone (Cig, $10 \mu \mathrm{mol} / \mathrm{L}$ ) for 1 hour, then cells were stimulated with TGF- $\beta 1$ (10 ng/mL) for 24 hours. Col $\alpha 1$ (III) mRNA expression was assessed by real-time RT-PCR (A). Western blot (B), immunofluorescence analysis (red) (E) and high content analysis (D) were used to evaluated Col $\alpha 1$ (III) protein. Col $\alpha 1$ (III) secreted into the medium was shown as arrows in (E). (C) BMSCs were transfected with scrambled siRNA or PPAR $\gamma$ siRNA for 48 hours, and Col $\alpha 1$ (I) mRNA was evaluated by real-time RT-PCR. All results were confirmed in three independent experiments. ${ }^{*} P<0.05$, compared with control; \# $P<0.05$, compared with TGF- $\beta 1$ group. Scale bars, $50 \mu \mathrm{m}$.

Myofibroblasts are the predominant collagen-producing cells in liver fibrosis. Upregulation of $\mathrm{Col} \alpha 1$ (I) and $\mathrm{Col} \alpha 1$ (III) is an essential event during BMSC differentiate toward myofibroblasts. Therefore, we sought to characterize the effects of PPAR $\gamma$ on the expression of Col $\alpha 1$ (I) and Col $\alpha 1$ (III) in BMSCs. As expected, all three PPAR $\gamma$ agonists, $15 \mathrm{~d}_{-} \mathrm{PGJ}_{2}$, troglitazone or ciglitazone blunted the increases of Col $\alpha 1$ (I) and Col $\alpha 1$ (III) mRNA expression in BMSCs treated with TGF- $\beta 1$ (Fig. $4 \mathrm{~A}$ and $5 \mathrm{~A}$ ). Western blot analysis exhibited similar results in protein level (Fig. 4B and 5B). In accord with $\alpha$-SMA, mRNA expressions of Col $\alpha 1$ (I) and Col $\alpha 1$ (III) were also increased in PPAR $\gamma$-knock-down cells (Fig. 4C and 5C).

Furthermore, immunofluorescence was also performed to study the effects of PPAR $\gamma$ on the protein expressions of $\mathrm{Col} \alpha 1$ (I) and $\mathrm{Col} \alpha 1$ (III) in BMSCs. The results showed that there were strong immunoreactivities for $\operatorname{Col} \alpha 1$ (I) and Col $\alpha 1$ (III) in BMSCs after treatment with TGF- $\beta 1$ (Fig. 4E and 5E), and collagen that was secreted into the medium was also detected by immunofluorescence (Fig. 4E and 5E, arrow). Manipulation of PPAR $\gamma$ ligands reduced the degree of positive staining for Col $\alpha 1$ (I) and Col $\alpha 1$ (III) induced by TGF- $\beta 1$ (Fig. 4E and 


\section{Cellular Physiology Cell Physiol Biochem 2015;37:2085-2100 \begin{tabular}{l|l|l|l|l}
\hline DOI: 10.1159/000438567 & () 2015 The Author(s). Published by S. Karger AG, Basel
\end{tabular}

\section{A}

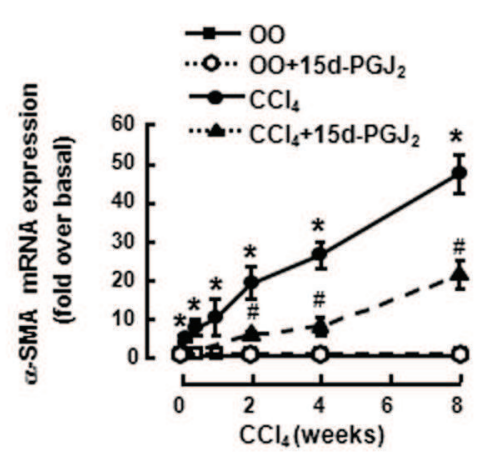

B

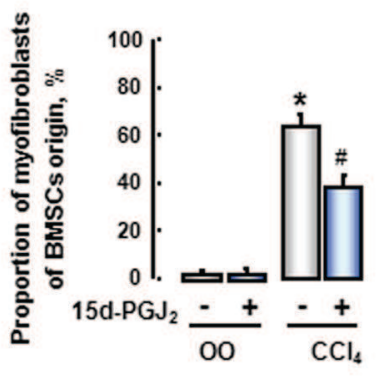

C

a-SMA / DAPI

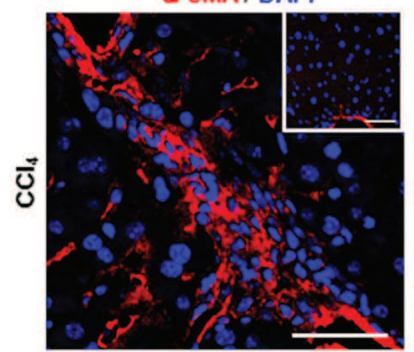

D

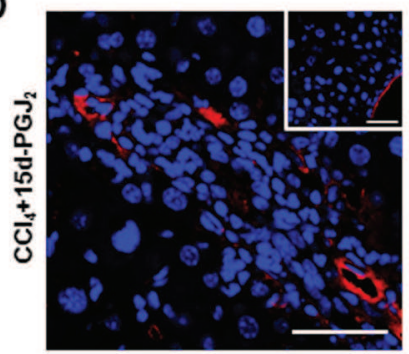

EGFP / DAPI
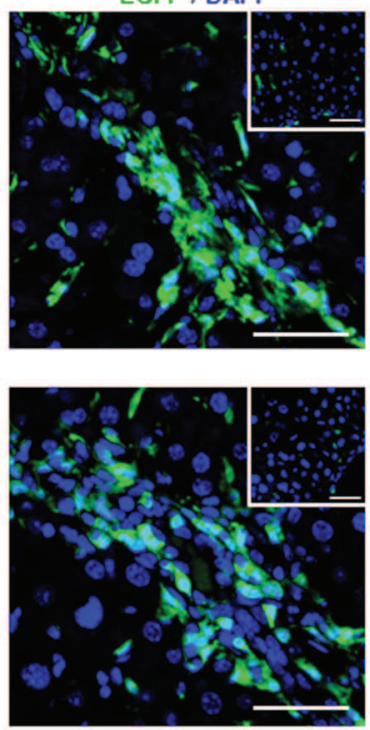

Merge
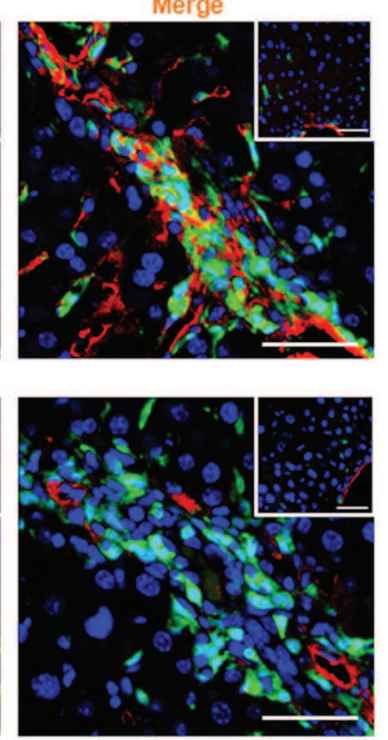

Fig. 6. Activated PPAR $\gamma$ inhibits BMSCs differentiate toward myofibroblasts during liver injury. (A) Mouse liver fibrosis was induced by injection of $\mathrm{CCl}_{4}$ twice per week for different time periods with or without $15 \mathrm{~d}-\mathrm{PGJ} \mathrm{J}_{2}$ administration ( $\mathrm{n}=7$ per group). mRNA of $\alpha$-SMA in liver tissues was detected with real-time RT-PCR. (B-D) ICR mice were lethally irradiated and received whole BM transplants from EGFP transgenic mice, followed by $\mathrm{CCl}_{4}$ injection twice per week for 4 weeks in the presence or absence of $15 \mathrm{~d}-\mathrm{PGJ} \mathrm{J}_{2}$ treatment ( $\mathrm{n}=7$ per group). The proportion of myofibroblasts from BMSCs was evaluated using Image-Pro Plus software (B). Representative immunofluorescence images of $\alpha$-SMA (red), EGFP (green) and merged fields to track myofibroblasts of BMSC origin (C and D). Insets in (C) were immunofluorescence images for olive oil (OO)-treated livers, and in (D) were livers of 00 group with $15 \mathrm{~d}-\mathrm{PGJ}{ }_{2}$. The nuclei were stained with DAPI (blue). ${ }^{*} P<0.05$ compared with 00 group. $\# P<0.05$, compared with $\mathrm{CCl}_{4}$ group without $15 \mathrm{~d}-\mathrm{PGJ}{ }_{2}$. Scale bars, $50 \mu \mathrm{m}$.

5E). High content analysis indicated that the increased total fluorescence intensities of Col $\alpha 1$ (I) and Col $\alpha 1$ (III) were attenuated by $15 \mathrm{~d}-\mathrm{PGJ}{ }_{2}$, roglitazone or ciglitazone (Fig. 4D and 5D). Altogether, these findings showed that PPAR $\gamma$ negatively governed BMSCs differentiate toward myofibroblasts.

Activated PPAR inhibits the differentiation of BMSCs toward myofibroblasts in mouse fibrotic liver

During liver injury, myofibroblasts are increased and its marker, $\alpha$-SMA, is up-regulated to contribute to liver fibrogenesis [29]. In the present study, we found that treatment with the natural ligand of PPAR $\gamma, 15 \mathrm{~d}-\mathrm{PG} \mathrm{f}_{2}$, reduced $\alpha$-SMA mRNA in liver fibrosis induced by different 


\section{Cellular Physiology Cell Physiol Biochem 2015;37:2085-2100

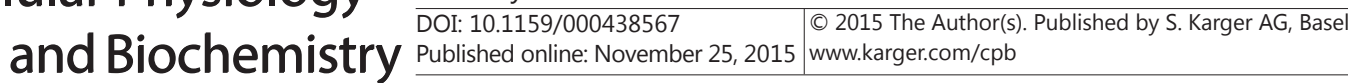 \\ Jia et al.: PPARY Negatively Regulates the Differentiation of BMSCs}

Fig. 7. $\operatorname{PPAR} \gamma$ activation suppresses collagen expression in liver fibrosis. Different time periods of $\mathrm{CCl}_{4}$ was used to induce mouse liver fibrosis with or without $15 \mathrm{~d}-\mathrm{PGJ}_{2}$ administration $(\mathrm{n}=7$ per group). (A) Expression of Col $\alpha 1$ (I) and Col $\alpha 1$ (III) mRNA levels in liver tissues were measured by real-time RT-PCR. (B) Representative images of Sirius Red staining in the absence or presence of $15 \mathrm{~d}-\mathrm{PGJ}_{2}$ after $\mathrm{CCl}_{4}$ administration. * $P<$ 0.05 compared with olive oil (00) group. \# $P<$ 0.05, compared with $\mathrm{CCl}_{4}$ group without $15 \mathrm{~d}-\mathrm{PGJ}_{2}$. Scale bars, $50 \mu \mathrm{m}$.

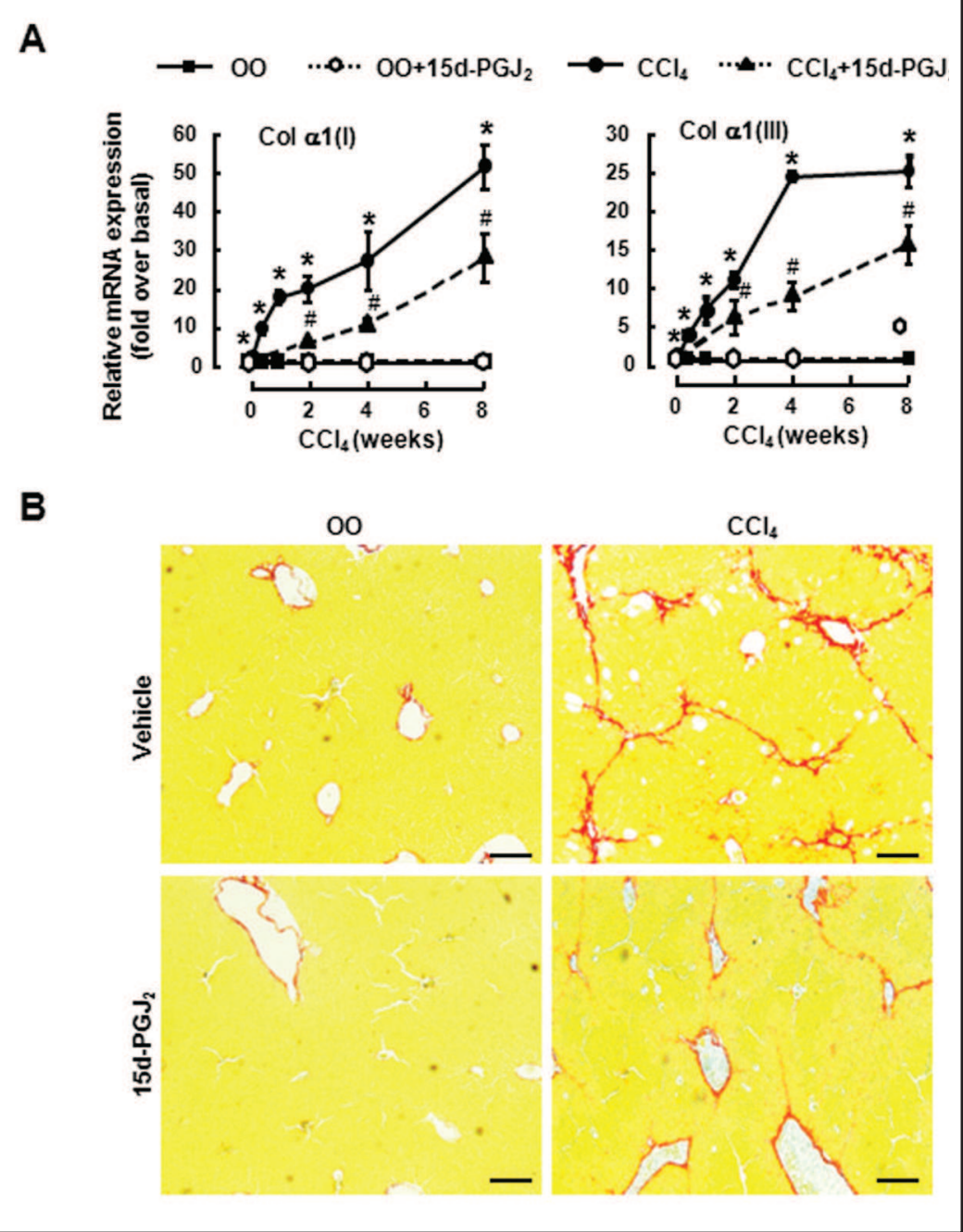

periods of $\mathrm{CCl}_{4}$ injection (Fig. 6A). Given that myofibroblasts are mostly BMSC-derived, we further determined the effect of PPAR $\gamma$ on BMSC differentiation toward myofibroblasts in vivo $\mathrm{BM}$ in the irradiated mice was reconstituted by transplanting BM cells from EGFP transgenic mice, and then the proportion of BMSC-derived myofibroblasts was measured. As shown in Fig. 6C, after $\mathrm{CCl}_{4}$ treatment, there was a strong expression of $\alpha$-SMA colocalizing with EGFP in the fibrotic areas, which indicated they were BMSC origin. However, $15 \mathrm{~d}-\mathrm{PGJ}{ }_{2}$ significantly inhibited the differentiation of BMSCs toward myofibroblasts in liver fibrogenesis (Fig. 6D), and markedly decreased the proportion of BMSC-derived myofibroblasts compared with $\mathrm{CCl}_{4}$ group without $15 \mathrm{~d}-\mathrm{PG} \mathrm{J}_{2}$ treatment (Fig. 6B). These results indicated that PPAR $\gamma$ activation could suppress BMSCs differentiate toward myofibroblasts in vivo.

\section{Activated PPAR $\gamma$ attenuates hepatic fibrosis}

Col $\alpha 1$ (I) and Col $\alpha 1$ (III) are the main ECM in fibrotic liver tissue [1, 2]. After injection of $\mathrm{CCl}_{4}$, there were dynamic changes in mRNA expressions of Col $\alpha 1$ (I) and Col $\alpha 1$ (III) in liver tissue, which markedly up-regulated in a way correlated with the progression of liver fibrosis (Fig. 7A). As expected, PPAR $\gamma$ activation by $15 \mathrm{~d}-\mathrm{PGJ} \mathrm{J}_{2}$ markedly decreased these mRNA levels (Fig. 7A). In addition, hepatic collagen deposition was further evaluated by morphometric analysis with Sirius red staining. As shown in Fig. 7B, collagen deposition was markedly attenuated after $15 \mathrm{~d}-\mathrm{PGJ} \mathrm{J}_{2}$ administration. These data suggest activation of PPAR $\gamma$ had anti-fibrotic properties. 


\section{Cellular Physiology Cell Physiol Biochem 2015;37:2085-2100 and Biochemistry Published online: November 25, 2015 www.karger.com/cpb \\ Jia et al.: PPARy Negatively Regulates the Differentiation of BMSCs}

\section{Discussion}

Liver fibrosis is a common pathological course of chronic hepatic diseases. So far, there is no effective and safe strategy for the prevention or inhibition of fibrogenesis in clinical practice. Differentiation of BMSCs toward myofibroblasts is an essential event for liver fibrogenesis, thus, elucidating the regulatory mechanisms in this process may shed light on the treatment of liver fibrosis. In the current study, we delineated the potential role of PPAR $\gamma$ in the differentiation of primary mouse BMSCs toward myofibroblasts. We found PPAR $\gamma$ negatively regulated BMSC differentiation toward myofibroblasts in liver fibrogenesis. Expression of PPAR $\gamma$ was reduced in fibrotic liver tissue. In addition, differentiation of BMSCs was accompanied by the decrease of PPAR $\gamma$ expression. Activated PPAR $\gamma$ by specific ligands could attenuate BMSC differentiation in vitro and in vivo, and alleviate liver fibrosis. These results critically revealed a mechanism underlying differentiation of BMSCs toward myofibroblasts.

Accumulating evidence suggests that levels of PPAR $\gamma$ were dramatically reduced in the process of fibrosis $[13,27,28,30,31]$, whereas overexpression of PPAR $\gamma$ could ameliorate the degree of fibrosis [32]. In the present study, the abundance of PPAR $\gamma$ was evidently reduced in fibrogenesis, similar to the reports in rats that PPAR $\gamma$ expression was down-regulated in fibrotic liver tissue induced by 2 or 8 weeks of $\mathrm{CCl}_{4}$ combined with ethyl alcohol treatment or caused by 10 days of BDL operation [28, 33, 34]. In addition, mRNA expressions of PPAR $\gamma$ and those fibrotic related molecules, such as TGF- $\beta 1, \alpha-S M A, C o l ~ \alpha 1$ (I) and Col $\alpha 1$ (III), were negative correlations. Intriguingly, PPAR $\gamma$ and plasminogen activator inhibitor-1 (PAI1 ), associated with fibrosis and implicated in its pathogenesis, were inversely correlated in skin [13]. In heart, PPAR $\gamma$ was also negatively correlated with tenascin-x, which was exclusively expressed in fibroblasts that can mediate fibrosis [35]. These results emphasize the importance of PPAR $\gamma$ in the pathogenesis of fibrosis in different tissues.

Several studies reveal that PPAR $\gamma$ was down-regulated in the differentiation of sorts of fibroblasts and myocytes toward myofibroblasts $[11,13,36]$. In our study, expression of PPAR $\gamma$ was remarkably decreased during BMSC differentiation toward myofibroblasts induced by TGF- $\beta 1$, similar to our previous report that expression of PPAR $\gamma$ almost couldn't be detected in human hepatic myofibroblasts [37]. In addition, the down-regulation of PPAR $\gamma$ by specific siRNA had favorable effect on the differentiation of BMSCs. In accordance, enhanced myofibroblast formation potential was observed in PPAR $\gamma$-deficient mouse fibroblasts [38]. BMSCs are multipotent cells with the potential to differentiate toward a variety of mesenchymal cells, such as adipocytes [39]. The decreased expression of PPAR $\gamma$, a transcription factor that related to fat-formation, might make BMSCs lost potential to differentiate toward adipocytes, but contribute to the differentiation toward myofibroblasts in the present study. This hypothesis is in agreement with the results in HSCs, another type fat-storing cell, that significant reduced expression of PPAR $\gamma$ was paralleled by activation of HSCs [32, 40-42]. It has been reported that the necdin-wnt pathway and a combination of methyl-CpG binding protein 2 (MeCP2), enhancer of zeste homolog 2 (EZH2) and miR132 cause epigenetic PPAR $\gamma$ repression and result in HSC activation $[43,44]$. In addition, PPAR $\gamma$ expression could be repressed by TGF- $\beta 1$ through increasing the binding of histone deacetylase 1 (HDAC1) and decreasing the levels of acetylated histone3 (AcH3) at the PPAR $\gamma$ promoter or via smad binding elements in the PPAR $\gamma$ gene promoter to negatively regulate the promoter activity of PPAR $\gamma$ gene in cardiac fibroblasts or HSCs $[11,24]$. However, the precise regulatory mechanism of PPAR $\gamma$ expression in BMSCs is scarce and should be valued in further research.

PPAR $\gamma$ needs to be activated by ligands to exert effects. Results presented here showed that either natural or synthetic ligands of PPAR $\gamma$ could suppress BMSC differentiate toward myofibroblasts induced by TGF- $\beta 1$ in vitro, with alleviation of $\alpha$-SMA, Col $\alpha 1$ (I) and Col $\alpha 1$ (III) expression. More importantly, we found activation of PPAR $\gamma$ by natural ligand could inhibit the differentiation of BMSCs toward myofibroblasts in liver fibrogenesis and decreased the proportion of BMSC-derived myofibroblasts. These results provide strong evidence for 


\section{Cellular Physiology Cell Physiol Biochem 2015;37:2085-2100

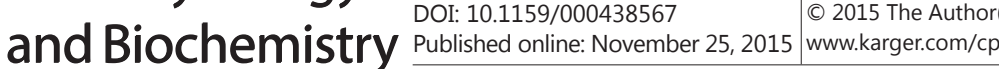 \\ Jia et al.: PPARy Negatively Regulates the Differentiation of BMSCs}

that activated PPAR $\gamma$ can negatively regulate BMSC differentiate toward myofibroblasts. In particular, serum concentrations of $15 \mathrm{~d}-\mathrm{PGJ}{ }_{2}$ in Caucasian patients with ongoing hepatic fibrogenesis and Chinese patients with hepatocellular carcinoma are elevated, which suggests that increased $15 \mathrm{~d}-\mathrm{PGJ} \mathrm{I}_{2}$ might trigger PPAR $\gamma$ activity to attempt to execute its beneficial effects [45]. Additionally, PPAR $\gamma$ activation by agonists attenuates skin and renal fibroblast differentiation $[12,46]$ and inhibits HSC activation [32, 42]. It is noteworthy that effects of activated PPAR $\gamma$ by different agonists may have diverse and complex roles in regulating cell differentiation. For instance, Da et al. [47] reported that PPAR $\gamma$ ligand, pioglitazone, did not suppress cultured HSC activation by assessment expression of $\alpha$-SMA and Col $\alpha 1$ (I).

Our previous result has indicated that sphingosine kinase/S1P/S1P receptor axis participates in the differentiation of BMSCs toward myofibroblasts [9]. In the present study, we found PPAR $\gamma$ negatively regulates BMSC differentiation toward myofibroblasts. There are several reports have linked PPAR $\gamma$ with S1P signaling pathway. In renal mesangial cells, synthetic PPAR $\gamma$ agonists thiazolidinediones up-regulate sphingosine kinase and intracellular S1P resulting in decrease expression of CTGF to causes an anti-fibrotic effect [48]. In addition, thiazolidinediones could increase the abundance of S1P receptor [49]. In turn, PPAR $\gamma$ is an intracellular target for S1P and S1P could activate PPAR $\gamma$ coactivator $1 \alpha($ PGC- $1 \alpha)[50,51]$. These findings might partially explain the effect of PPAR $\gamma$ on BMSC differentiation toward myofibroblasts and its inhibitory function in liver fibrosis. However, the relationship between PPAR $\gamma$ and S1P pathway remains controversial. In 3T3-L1 preadipocytes, S1P down-regulates the expression of PPAR $\gamma$ [52], which reflects the complexity of signaling cascades in a biological system.

An important issue of PPAR $\gamma$ is that PPAR $\gamma$ carries out its function requiring translocation from cytoplasm to nucleus, such as in the study of PPAR $\gamma$ governs the differentiation of skin fibroblasts [46]. Besides regulating target gene expression directly, PPAR $\gamma$ could interact with other cell signaling pathways, including fibrotic-related events in cells. It has been reported that PPAR $\gamma$ is capable of binding to Smad3 and p-Smad3, and prevents nuclear accumulation of p-Smad3, resulting in disruption of TGF- $\beta 1$ signaling [53]. Activated PPAR $\gamma$ by rosiglitazone reduced the induction of the early-immediate transcription factor Egr-1, a mediator of non-Smad TGF- $\beta 1$ signaling, to exhibit its antifibrotic function [54]. Furthermore, albumin may be a downstream effector of PPAR $\gamma$ in phenotypic switch of pancreatic stellate cells (PSCs) [55], and PPAR $\gamma$ activation might ameliorate renal fibrotic lesions via hepatocyte growth factor (HGF) [56]. However, whether these molecular mechanisms mediate the effects of PPAR $\gamma$ on BMSC differentiation toward myofibroblasts need to be further explored.

In summary, our results demonstrate that PPAR $\gamma$ is a negative regulator in BMSC differentiation toward myofibroblasts in liver fibrogenesis. Decrease in PPAR $\gamma$ expression is accompanied by the differentiation of BMSCs toward myofibroblasts, and activated PPAR $\gamma$ by agonists inhibits BMSC differentiation in vitro and in vivo, and causes an attenuation of liver fibrosis. Consequently, these findings expand our knowledge on the regulatory mechanisms of BMSC differentiation, and make PPAR $\gamma$ to be a promising target for treatment of liver fibrotic diseases.

\section{Abbreviations}

PPAR $\gamma$ (peroxisome proliferator-activated receptor gamma); BMSCs (bone marrowderived mesenchymal stem cells); $\alpha$-SMA ( $\alpha$-smooth muscle actin); $15 \mathrm{~d}-\mathrm{PG} \mathrm{f}_{2}$ (15-Deoxy$\Delta^{12,14}$-prostaglandin $\mathrm{J}_{2}$ ); TGF- $\beta 1$ (transforming growth factor $\beta 1$ ).

\section{Acknowledgements}

This work was supported by grants from the National Natural and Science Foundation of China $(81430013,81300335)$ and the Project of Construction of Innovative Teams and 


\section{Cellular Physiology Cell Physiol Biochem 2015;37:2085-2100 \begin{tabular}{l|l|l} 
10.1159/000438567 & ( ) 2015 The Author(s). Published by S. Karger AG, Basel
\end{tabular} and Biochemistry Published online: November 25, 2015 www.karger.com/cpb \\ Jia et al.: PPARY Negatively Regulates the Differentiation of BMSCs}

Teacher Career Development for Universities and Colleges under Beijing Municipality (IDHT20150502).

\section{Disclosure Statement}

The authors declared that they have no conflicts of interest related to this work.

\section{References}

1 Bataller R, Brenner DA: Liver fibrosis. J Clin Invest 2005;115:209-218.

2 Friedman SL: Mechanisms of hepatic fibrogenesis. Gastroenterology 2008;134:1655-1669.

3 Xiao Y, Qu C, Ge W, Wang B, Wu J, Xu L, Chen Y: Depletion of thymosin beta4 promotes the proliferation, migration, and activation of human hepatic stellate cells. Cell Physiol Biochem 2014;34:356-367.

4 Kordes C, Sawitza I, Gotze S, Haussinger D: Hepatic stellate cells support hematopoiesis and are liverresident mesenchymal stem cells. Cell Physiol Biochem 2013;31:290-304.

5 Russo FP, Alison MR, Bigger BW, Amofah E, Florou A, Amin F, Bou-Gharios G, Jeffery R, Iredale JP, Forbes SJ: The bone marrow functionally contributes to liver fibrosis. Gastroenterology 2006;130:1807-1821.

6 Li C, Kong Y, Wang H, Wang S, Yu H, Liu X, Yang L, Jiang X, Li L, Li L: Homing of bone marrow mesenchymal stem cells mediated by sphingosine 1-phosphate contributes to liver fibrosis. J Hepatol 2009;50:11741183.

7 De Bleser PJ, Niki T, Rogiers V, Geerts A: Transforming growth factor-beta gene expression in normal and fibrotic rat liver. J Hepatol 1997;26:886-893.

8 Molina-Molina M, Lario S, Luburich P, Ramirez J, Carrion MT, Xaubet A: quantifying plasma levels of transforming growth factor beta1 in idiopathic pulmonary fibrosis. Arch Bronconeumol 2006;42:380-383.

9 Yang L, Chang N, Liu X, Han Z, Zhu T, Li C, Yang L, Li L: Bone marrow-derived mesenchymal stem cells differentiate to hepatic myofibroblasts by transforming growth factor-beta1 via sphingosine kinase/ sphingosine 1-phosphate (s1p)/s1p receptor axis. Am J Pathol 2012;181:85-97.

10 Matsuzaki K: Smad phosphoisoform signals in acute and chronic liver injury: similarities and differences between epithelial and mesenchymal cells. Cell Tissue Res 2012;347:225-243.

11 Gong K, Chen YF, Li P, Lucas JA, Hage FG, Yang Q Nozell SE, Oparil S, Xing D: Transforming growth factorbeta inhibits myocardial ppargamma expression in pressure overload-induced cardiac fibrosis and remodeling in mice. J Hypertens 2011;29:1810-1819.

12 Wang W, Liu F, Chen N: Peroxisome proliferator-activated receptor-gamma (ppar-gamma) agonists attenuate the profibrotic response induced by tgf-beta1 in renal interstitial fibroblasts. Mediators Inflamm 2007;2007:62641.

13 Wei J, Ghosh AK, Sargent JL, Komura K, Wu M, Huang QQ Jain M, Whitfield ML, Feghali-Bostwick C, Varga J: Ppargamma downregulation by tgfss in fibroblast and impaired expression and function in systemic sclerosis: a novel mechanism for progressive fibrogenesis. PLoS One 2010;5:e13778.

14 Ferguson HE, Kulkarni A, Lehmann GM, Garcia-Bates TM, Thatcher TH, Huxlin KR, Phipps RP, Sime PJ: Electrophilic peroxisome proliferator-activated receptor-gamma ligands have potent antifibrotic effects in human lung fibroblasts. Am J Respir Cell Mol Biol 2009;41:722-730.

15 Evans RM: The steroid and thyroid hormone receptor superfamily. Science 1988;240:889-895.

16 Kota BP, Huang TH, Roufogalis BD: An overview on biological mechanisms of ppars. Pharmacol Res 2005;51:85-94.

17 Knouff C, Auwerx J: Peroxisome proliferator-activated receptor-gamma calls for activation in moderation: lessons from genetics and pharmacology. Endocr Rev 2004;25:899-918.

18 Lehrke M, Lazar MA: The many faces of ppargamma. Cell 2005;123:993-999.

19 Rosen ED, Spiegelman BM: Ppargamma: a nuclear regulator of metabolism, differentiation, and cell growth. J Biol Chem 2001;276:37731-37734.

20 Imano E, Kanda T, Nakatani Y, Nishida T, Arai K, Motomura M, Kajimoto Y, Yamasaki Y, Hori M: Effect of troglitazone on microalbuminuria in patients with incipient diabetic nephropathy. Diabetes Care 1998;21:2135-2139. 


\section{Cellular Physiology Cell Physiol Biochem 2015;37:2085-2100 \begin{tabular}{ll|l}
\cline { 2 - 3 } DOI: 10.1159/000438567 & ( ) 2015 The Author(s). Published by S. Karger AG, Basel
\end{tabular} and Biochemistry Published online: November 25, 2015 www.karger.com/cpb}

Jia et al.: PPARy Negatively Regulates the Differentiation of BMSCs

21 Bakris GL, Ruilope LM, McMorn SO, Weston WM, Heise MA, Freed MI, Porter LE: Rosiglitazone reduces microalbuminuria and blood pressure independently of glycemia in type 2 diabetes patients with microalbuminuria. J Hypertens 2006;24:2047-2055.

22 Deng YL, Xiong XZ, Cheng NS: Organ fibrosis inhibited by blocking transforming growth factor-beta signaling via peroxisome proliferator-activated receptor gamma agonists. Hepatobiliary Pancreat Dis Int 2012;11:467-478.

23 Gonzalez EG, Selvi E, Balistreri E, Akhmetshina A, Palumbo K, Lorenzini S, Lazzerini PE, Montilli C, Capecchi PL, Lucattelli M, Baldi C, Gianchecchi E, Galeazzi M, Pasini FL, Distler JH: Synthetic cannabinoid ajulemic acid exerts potent antifibrotic effects in experimental models of systemic sclerosis. Ann Rheum Dis 2012;71:1545-1551.

24 Zheng S, Chen A: Disruption of transforming growth factor-beta signaling by curcumin induces gene expression of peroxisome proliferator-activated receptor-gamma in rat hepatic stellate cells. Am J Physiol Gastrointest Liver Physiol 2007;292:G113-G123.

25 Uchinami H, Seki E, Brenner DA, D’Armiento J: Loss of mmp 13 attenuates murine hepatic injury and fibrosis during cholestasis. Hepatology 2006;44:420-429.

26 Chang N, Xiu L, Li L: Sphingosine 1-phosphate receptors negatively regulate collagen type i/iii expression in human bone marrow-derived mesenchymal stem cell. J Cell Biochem 2014;115:359-367.

27 Shi-wen X, Eastwood M, Stratton RJ, Denton CP, Leask A, Abraham DJ: Rosiglitazone alleviates the persistent fibrotic phenotype of lesional skin scleroderma fibroblasts. Rheumatology (Oxford) 2010;49:259-263.

28 Guo C, Xu L, He Q, Liang T, Duan X, Li R: Anti-fibrotic effects of puerarin on ccl4-induced hepatic fibrosis in rats possibly through the regulation of ppar-gamma expression and inhibition of pi3k/akt pathway. Food Chem Toxicol 2013;56:436-442.

29 Han Z, Zhu T, Liu X, Li C, Yue S, Liu X, Yang L, Yang L, Li L: 15-deoxy-delta12,14 -prostaglandin j2 reduces recruitment of bone marrow-derived monocyte/macrophages in chronic liver injury in mice. Hepatology 2012;56:350-360.

30 Meng Z, Yu XH, Chen J, Li L, Li S: Curcumin attenuates cardiac fibrosis in spontaneously hypertensive rats through ppar-gamma activation. Acta Pharmacol Sin 2014;35:1247-1256.

31 Periasamy S, Hsu DZ, Chang PC, Liu MY: Sesame oil attenuates nutritional fibrosing steatohepatitis by modulating matrix metalloproteinases-2, 9 and ppar-gamma. J Nutr Biochem 2014;25:337-344.

32 Yang L, Chan CC, Kwon OS, Liu S, McGhee J, Stimpson SA, Chen LZ, Harrington WW, Symonds WT, Rockey DC: Regulation of peroxisome proliferator-activated receptor-gamma in liver fibrosis. Am J Physiol Gastrointest Liver Physiol 2006;291:G902-G911.

33 Kumar V, Mundra V, Mahato RI: Nanomedicines of hedgehog inhibitor and ppar-gamma agonist for treating liver fibrosis. Pharm Res 2014;31:1158-1169.

34 Wang Z, Xu JP, Zheng YC, Chen W, Sun YW, Wu ZY, Luo M: Peroxisome proliferator-activated receptor gamma inhibits hepatic fibrosis in rats. Hepatobiliary Pancreat Dis Int 2011;10:64-71.

35 Jing L, Zhou LJ, Zhang FM, Li WM, Sang Y: Tenascin-x facilitates myocardial fibrosis and cardiac remodeling through transforming growth factor-beta1 and peroxisome proliferator-activated receptor gamma in alcoholic cardiomyopathy. Chin Med J (Engl) 2011;124:390-395.

36 Qian J, Niu M, Zhai X, Zhou Q, Zhou Y: Beta-catenin pathway is required for tgf-beta1 inhibition of ppargamma expression in cultured hepatic stellate cells. Pharmacol Res 2012;66:219-225.

37 Li L, Tao J, Davaille J, Feral C, Mallat A, Rieusset J, Vidal H, Lotersztajn S: 15-deoxy-delta 12,14-prostaglandin $\mathrm{j} 2$ induces apoptosis of human hepatic myofibroblasts. A pathway involving oxidative stress independently of peroxisome-proliferator-activated receptors. J Biol Chem 2001;276:38152-38158.

38 Kapoor M, McCann M, Liu S, Huh K, Denton CP, Abraham DJ, Leask A: Loss of peroxisome proliferatoractivated receptor gamma in mouse fibroblasts results in increased susceptibility to bleomycin-induced skin fibrosis. Arthritis Rheum 2009;60:2822-2829.

39 Pittenger MF, Mackay AM, Beck SC, Jaiswal RK, Douglas R, Mosca JD, Moorman MA, Simonetti DW, Craig S, Marshak DR: Multilineage potential of adult human mesenchymal stem cells. Science 1999;284:143-147.

40 Marra F, Efsen E, Romanelli RG, Caligiuri A, Pastacaldi S, Batignani G, Bonacchi A, Caporale R, Laffi G, Pinzani M, Gentilini P: Ligands of peroxisome proliferator-activated receptor gamma modulate profibrogenic and proinflammatory actions in hepatic stellate cells. Gastroenterology 2000;119:466-478. 


\section{Cellular Physiology Cell Physiol Biochem 2015;37:2085-2100 \begin{tabular}{l|l|l|l}
\cline { 2 - 3 } DOI: 10.1159/000438567 & ( ) 2015 The Author(s). Published by S. Karger AG, Basel
\end{tabular} and Biochemistry Published online: November 25, 2015 www.karger.com/cpb}

Jia et al.: PPARY Negatively Regulates the Differentiation of BMSCs

41 Miyahara T, Schrum L, Rippe R, Xiong S, Yee HJ, Motomura K, Anania FA, Willson TM, Tsukamoto H: Peroxisome proliferator-activated receptors and hepatic stellate cell activation. J Biol Chem 2000;275:35715-35722.

42 Shafiei MS, Shetty S, Scherer PE, Rockey DC: Adiponectin regulation of stellate cell activation via ppargamma-dependent and -independent mechanisms. Am J Pathol 2011;178:2690-2699.

43 Zhu NL, Wang J, Tsukamoto H: The necdin-wnt pathway causes epigenetic peroxisome proliferatoractivated receptor gamma repression in hepatic stellate cells. J Biol Chem 2010;285:30463-30471.

44 Mann J, Chu DC, Maxwell A, Oakley F, Zhu NL, Tsukamoto H, Mann DA: Mecp2 controls an epigenetic pathway that promotes myofibroblast transdifferentiation and fibrosis. Gastroenterology 2010;138:705714, 711-714.

45 Gressner OA, Gao C, Rehbein K, Lahme B, Siluschek M, Berg T, Muller T, Gressner AM: Elevated concentrations of 15-deoxy-delta12,14-prostaglandin $\mathrm{j} 2$ in chronic liver disease propose therapeutic trials with peroxisome proliferator activated receptor gamma-inducing drugs. Liver Int 2009;29:730-735.

46 Ghosh AK, Bhattacharyya S, Lakos G, Chen SJ, Mori Y, Varga J: Disruption of transforming growth factor beta signaling and profibrotic responses in normal skin fibroblasts by peroxisome proliferator-activated receptor gamma. Arthritis Rheum 2004;50:1305-1318.

47 Da SMA, Abarca-Quinones J, Horsmans Y, Starkel P, Leclercq IA: Peroxisome proliferated-activated receptor gamma ligand, pioglitazone, does not prevent hepatic fibrosis in mice. Int J Mol Med 2007;19:105-112.

48 Koch A, Volzke A, Wunsche C, Meyer ZHD, Huwiler A, Pfeilschifter J: Thiazolidinedione-dependent activation of sphingosine kinase 1 causes an anti-fibrotic effect in renal mesangial cells. Br J Pharmacol 2012;166:1018-1032.

49 Koch A, Volzke A, Puff B, Blankenbach K, Meyer ZHD, Huwiler A, Pfeilschifter J: Ppargamma agonists upregulate sphingosine 1-phosphate (s1p) receptor 1 expression, which in turn reduces s1p-induced [ca(2+)]i increases in renal mesangial cells. Biochim Biophys Acta 2013;1831:1634-1643.

50 Shen Z, Liu C, Liu P, Zhao J, Xu W: Sphingosine 1-phosphate (s1p) promotes mitochondrial biogenesis in hep g2 cells by activating peroxisome proliferator-activated receptor gamma coactivator 1alpha (pgc1alpha). Cell Stress Chaperones 2014;19:541-548.

51 Parham KA, Zebol JR, Tooley KL, Sun WY, Moldenhauer LM, Cockshell MP, Gliddon BL, Moretti PA, Tigyi G, Pitson SM, Bonder CS: Sphingosine 1-phosphate is a ligand for peroxisome proliferator-activated receptorgamma that regulates neoangiogenesis. FASEB J 2015;29:3638-53.

52 Moon MH, Jeong JK, Lee YJ, Seol JW, Park SY: Sphingosine-1-phosphate inhibits the adipogenic differentiation of 3t3-11 preadipocytes. Int J Mol Med 2014;34:1153-1158.

53 Lin LC, Hsu SL, Wu CL, Liu WC, Hsueh CM: Peroxisome proliferator-activated receptor gamma (ppargamma) plays a critical role in the development of tgfbeta resistance of h460 cell. Cell Signal 2011;23:1640-1650.

54 Wu M, Melichian DS, Chang E, Warner-Blankenship M, Ghosh AK, Varga J: Rosiglitazone abrogates bleomycin-induced scleroderma and blocks profibrotic responses through peroxisome proliferatoractivated receptor-gamma. Am J Pathol 2009;174:519-533.

55 Kim N, Choi S, Lim C, Lee H, Oh J: Albumin mediates ppar-gamma or c/ebp-alpha-induced phenotypic changes in pancreatic stellate cells. Biochem Biophys Res Commun 2010;391:640-644.

56 Li Y, Wen X, Spataro BC, Hu K, Dai C, Liu Y: Hepatocyte growth factor is a downstream effector that mediates the antifibrotic action of peroxisome proliferator-activated receptor-gamma agonists. J Am Soc Nephrol 2006;17:54-65. 